\title{
Potential Use of Multipurpose Paulownia elongata Tree as an Animal Feed Resource
}

\author{
Whitley Marshay Stewart, Brajesh Nanda Vaidya, Ajit Kumar Mahapatra, \\ Thomas Howard Terrill, Nirmal Joshee*
}

Agricultural Research Station, Fort Valley State University, Fort Valley, GA 31030, USA

Email: *josheen@fvsu.edu

How to cite this paper: Stewart, W.M., Vaidya, B.N., Mahapatra, A.K., Terrill, T.H. and Joshee, N. (2018) Potential Use of Multipurpose Paulownia elongata Tree as an Animal Feed Resource. American Journal of Plant Sciences, 9, 1212-1227.

https://doi.org/10.4236/ajps.2018.96090

Received: March 1, 2018

Accepted: May 21, 2018

Published: May 24, 2018

Copyright $\odot 2018$ by authors and Scientific Research Publishing Inc. This work is licensed under the Creative Commons Attribution International License (CC BY 4.0).

http://creativecommons.org/licenses/by/4.0/

\begin{abstract}
Paulownia is known as an economically important multipurpose tree genus due to its fast growth and short-rotation harvesting for timber. There is interest in growing Paulownia species as a woody biofuel crop. There are reports on its leaves being rich in nitrogen and double as good fodder, as well as fertilizer (green manure). Nutritional properties of Paulownia elongata leaves collected at monthly intervals from Paulownia Demonstration Plot, Fort Valley State University (FVSU), Fort Valley, Georgia, USA, from April to November, 2011, were studied. The leaves were dried and analyzed for crude protein $(\mathrm{CP})$, neutral detergent fiber (NDF), acid detergent fiber (ADF), acid detergent lignin (ADL), fat, gross energy, and ash content. The $\mathrm{CP}, \mathrm{NDF}, \mathrm{ADF}$, $\mathrm{ADL}$, fat and ash content ranged from $14 \%-23 \%, 29 \%-55 \%, 18 \%-42 \%$, $10 \%-22 \%, 2 \%-4 \%$, and $6 \%-9 \%$, respectively, indicating that Paulownia leaves have potential as a feed resource for livestock. Forage potential research was followed up by developing protocols to manufacture feed pellets with $75 \%$ and 95\% leaf component and assessing their physical properties. There is an economic market potential for the by-products of Paulownia, which is usually grown for timber.
\end{abstract}

\section{Keywords}

Feed Pellets, Fodder, Forage Analysis, Nutritional Properties

\section{Introduction}

Globally, 36 percent of all calories produced annually are fed to animals [1] and the US, Brazil, and China lead the world in producing animal feed. It is imperative that alternate non-food plant resources are identified to assist the animal feed industry. Low quality and inadequate quantity of feeds are a major con- 
straint limiting livestock productivity all over the world. Fodder trees that may be used on smallholder farms have a number of advantages as a source of fodder. Fodder trees are not susceptible to sudden climatic changes and produce fodder even during dry periods. Further, importance of trees, shrubs and herbs as a fodder source has been suggested due to their nutrition capacity (compared to grasses, fodder trees, shrubs and herbs have relatively higher concentrations of crude protein, minerals, and neutral detergent fiber) for browsing and grazing animals in areas of poor quality pastures for longer periods of time during the year [2].

Trees like Paulownia that are fast growing and coppice well serve multiple purposes such as the production of large quantities of leafy biomass for fodder, to use as mulch and to control soil erosion. Paulownia species can be used as a suitable companion for intercropping as they do not compete with food crops for nutrients [3]. Besides, in many parts of the world, trees are a valuable source for firewood, timber for construction and fencing, and provide shade for animals [4]. Paulownia elongata (family Paulowniaceae) is economically important as a short-rotation tree bioenergy crop [5] [6]. Historical account of the arrival of genus Paulownia in the United States and its current status in the state of Georgia has been recorded by Snow [7] but no quantitative data are available on tree growth and leaf analysis for Georgia conditions. Paulownia wood is known for its moisture resistance and flame retardant properties [8], as well as its flexibility and distinctive texture, grain, and color [9]. As a fast-growing tree, Paulownia has also been suggested as a bioenergy crop, potentially useful for both carbon sequestration or as a biomass source for conversion to transportation fuel [6] [10]. In addition to its usefulness as wood and related industrial products [5], the fruits, wood, bark, roots, seeds, leaves, and flowers of Paulownia have also been reported to have a number of useful medicinal properties [11] [12]. The fallen leaves of Paulownia improve soil quality by increasing organic matter and the nectariferous flowers are rich source of nutritious honey [9] [11].

The potential use of Paulownia foliage as livestock fodder has thus far received less attention. It has been reported that $P$. tomentosa, $P$. fortunei, and $P$. elongata lamina are palatable, contributing to nutritional values that are suitable for goat browse [13]. There have been reports of several fodder shrubs and trees that may moderately or completely replace concentrated feeds without decreasing digestion or growth of small ruminants like sheep and goats [14]. Furthermore, goats are efficient browsers and not only possess the ability to adapt to harsh environments, but also have the capability to use woody species and low-quality forages better than sheep and cattle [15] [16].

Once a Paulownia tree is established, it is able to regenerate from stump sprouts (coppicing), which means that it does not have to be replanted for numerous rotations [17]. This is a cost advantage over many other tree species that do not possess this trait. In fodder production, this ability to coppice is a vital asset which allows the plants to be cut down more than once, as needed, in the growing season [17]. While it is known that Paulownia foliage can be used as a 
browse resource for goats [13], there has been no literature available to provide quantitative data on the use of $P$. elongata as forage for livestock.

The advantages of feeding pellets to animals are easy storage and feeding (less wastage, less dust, lower labor costs) and more precise control over the desired ration for groups of animals or for individual animals with greater nutritional needs, like lactating females or immature stock. Hay wastage can be extreme under conditions of high humidity, and pellet feeding is often more profitable. In order to produce quality pellets, it is necessary to determine their physical and mechanical properties. This will ensure appropriately designed pellets, as well as help to determine a suitable means of storage, and these properties will also determine the method of transportation and handling systems [18] [19] [20] [21]. Physical, thermal and mechanical properties have been studied for a variety of different pellets, including alfalfa [22] [23], corn-soybean [24], switch grass [19], and Lespedeza cuneata [20]. However, there is no evidence existing in the literature about physical properties of $P$. elongata pellets.

Georgia is a large agricultural state. There is a huge demand for nutritious feed for poultry, small ruminants and other livestock animals. As Paulownia species are mainly grown for timber and exhibit great potential as a bioenergy crop [6], additional value added products will help rural economy generating multiple revenue streams. In our previous research we reported suitability of growing $P$. elongata and biomass and carbon sequestration data of three years old trees in the middle Georgia conditions [6]. During the same period leaf samples were collected and this study was carried out to learn about the availability window of Paulownia leaves in the field, their nutritional profile and standardization of pellet making process.

\section{Materials and Methods}

\subsection{Planting Paulownia under Middle Georgia Conditions}

A research plot designated as "Paulownia Demonstration Plot" was established in the year 2009 at the experimental farm of FVSU, Fort Valley, Georgia $\left(32^{\circ} 31^{\prime} 14.6^{\prime \prime} \mathrm{N} 83^{\circ} 52^{\prime} 12.1^{\prime \prime} \mathrm{W}\right)$. Two plots of $P$. elongata were planted to study the suitability of growing Paulownia under middle Georgia conditions. This area is described as 'Southern Coastal Plains' in terms of major soil province, consisting of red clayish top soil with hard pan below. The average high temperature is $32.7^{\circ} \mathrm{C}$ in the month of July/August and low temperature is $1.1^{\circ} \mathrm{C}$ in January. Annual average precipitation in Fort Valley is $9.67 \mathrm{~cm}$. Tissue cultured, hardened $P$. elongata trees at 6 - 8 leaf stage were obtained from the World Paulownia Institute, Lenox, GA and planted in two plots of land measuring 1.01 ha each during the last week of April. Soil $\mathrm{pH}$ determination indicated an acidic soil with $\mathrm{pH}$ in the range of 5.5. Timber and bioenergy plots received 5 tons each top-dress lime application to bring soil $\mathrm{pH}$ in the range of 6.5, suitable for Paulownia growth. After two months of initial establishment, the entire experimental plot received chicken litter as the only nutrient supplement at 5 tons/ha. No watering or application of fertilizer was done once trees were established, which 
took about 4 - 6 weeks. Annual trimming of branches was done during the winter in timber plot. One plot was designated as a bioenergy plot with trees at 2.44 $\mathrm{m} \times 2.44 \mathrm{~m}$ (1680 trees/ha) spacing, whereas another plot was designed as a timber plot, providing higher spacing to the trees at $3.66 \mathrm{~m} \times 3.66 \mathrm{~m}(741$ trees/ha).

\subsection{Collection and Processing of Forage}

Fresh leaves were collected during April to November 2011 from 30 months old $P$. elongata trees growing in the bioenergy and timber plots. Average sized leaves free of disease infections and insect damage were gathered and after removing petioles, were put into three labeled paper bags. Each of the paper bags were weighed, tared and weighed again with fresh leaf samples. All weights were recorded. Leaf samples were then placed into a dryer (Thelco Laboratory Oven, Precision Scientific, Winchester, VA, USA) set at $50^{\circ} \mathrm{C}$ for 3 days. After drying and re-weighing, samples were crushed in a bucket after removing leftover petioles or leaf veins. Approximately $100 \mathrm{~g}$ of each sample were then ground in a Cyclotec sample mill (Foss, Eden Prairie, MN, USA) to pass a one mm screen and placed in Ziploc Bags (S.C. Johnson Co., Racine, WI, USA), with sample number, plot number, replicate number, month, and year recorded for further analysis.

\subsection{Chemical Analyses}

Chemical analyses were carried out as per the methods described in Van Soest [25], AOAC protocols [26] and Kirsten [27]. Inductively coupled plasma (ICP) method [28] was used for determination of macro- and micronutrients.

All dried and ground leaf samples were analyzed for dry matter (DM), ash, nitrogen $(\mathrm{N})$, fat content, gross energy, mineral concentrations, neutral detergent fiber (NDF), acid detergent fiber (ADF), and acid detergent lignin (ADL). Analysis of nitrogen was completed using a Carbon/Nitrogen analyzer (Vario Max, Elementar Americas Inc., Mt. Laurel, NJ, USA), with crude protein (CP) calculated as $\mathrm{N} \times 6.25$. Fiber analyses $(\mathrm{NDF}, \mathrm{ADF}$, and ADL) were completed using the method of Van Soest [25] using an ANKOM $^{200 / 220}$ Fiber Analyzer (ANKOM Technology, Macedon, NY, USA). Dry matter, ash, and fat content were determined using AOAC protocols [26]. All forage quality data are presented on a dry matter basis. The energy content of biomass is determined by its calorific value which is influenced by elemental composition of biomass, moisture, and ash content. Gross energy and mineral analyses were performed using Parr 6400 Oxygen Bomb Calorimeter (Parr Instrument Company, Moline, Il, USA). To maintain quality control, a duplicated sample was run after every five samples. The method for determining carbon, hydrogen, nitrogen and sulfur, and sulfur alone was as described by Kirsten [27].

\subsection{Inductively Coupled Plasma (ICP) Method Procedure}

An Inductively-Coupled Plasma (ICP) method [28] was used for determination 
of phosphorus $(\mathrm{P})$, potassium $(\mathrm{K})$, calcium $(\mathrm{Ca})$, magnesium $(\mathrm{Mg})$, manganese $(\mathrm{Mn})$, iron $(\mathrm{Fe})$, aluminum $(\mathrm{Al})$, boron $(\mathrm{B})$, copper $(\mathrm{Cu})$, zinc $(\mathrm{Zn})$, sodium $(\mathrm{Na})$, lead $(\mathrm{Pb})$, cadmium $(\mathrm{Cd})$, nickel $(\mathrm{Ni})$, chromium $(\mathrm{Cr})$, and molybdenum (Mo).

\subsection{Plant Tissue Digestion}

\subsubsection{Nitric Acid $\left(\mathrm{HNO}_{3}\right)$-Microwave Method}

The USEPA method 3052 [29] was used for plant tissue digestion and micronutrient analyses. In brief, the method is as follows: samples $(0.5 \mathrm{~g})$ were weighed out and placed in fluorocarbon polymer microwave vessels with $10 \mathrm{~mL}$ concentrated $\left(\mathrm{HNO}_{3}\right)$ added to each vessel. The vessels were sealed, placed in a microwave digester (CEM Mars 6 Microwave, Matthews, NC, USA), and heated at $200^{\circ} \mathrm{C}$ for $30 \mathrm{~min}$. The digests (solutions) were transferred quantitatively into volumetric flasks and brought to $100 \mathrm{~mL}$ volume with deionized water. The solutions were then analyzed for various elements using EPA Method 200.8 [28] by Inductively Coupled Plasma-Optical Emission Spectroscopy (ICP-OES) (Spectro Arcos FHS16, Kleve, Germany).

\subsubsection{Materials Preparation and Pelletizing Process}

Ground, dried, and sieved leaf powder was used for making pellets and study physical properties. The $P$. elongata leaf pellets were manufactured at the Georgia Small Ruminant Research and Extension Center, FVSU, Fort Valley, GA., using a laboratory pellet mill (Series CL, California Pellet Mill Co., Crawfordsville, IN, USA). Pellets were made using two different ingredient types, and their compositions are presented in Table 1.

\subsubsection{Evaluation of Pellet Dimensions and Bulk Properties}

Moisture content of the pellets was determined using Mahapatra procedures [20]. Linear dimensions, namely, length and diameter of ten randomly selected cylindrical pellets were measured using a Vernier caliper (Fowler Tools and Instruments, Newton, MA, USA). Unit mass was obtained by weighing each pellet using a precision digital balance (Model A-250, Denver Instruments, Arvada, CO, USA). Bulk density was calculated as the ratio of the mass of pellets to the volume of the container. The pellets were leveled with the top surface of the

Table 1. Composition of $75 \%$ and $95 \%$ Paulownia pellets.

\begin{tabular}{ccc}
\hline Composition & $\begin{array}{c}75 \% \text { Paulownia pellets } \\
\text { \% (w/w, dry matter basis })\end{array}$ & $\begin{array}{c}\text { 95\% Paulownia pellets } \\
\text { \% (w/w, dry matter basis })\end{array}$ \\
\hline Paulownia leaf meal & 75 & 95 \\
Trace mineralized salt & 0.5 & 2.5 \\
Vitamin premixed & 0.5 & 2.5 \\
Ground corn & 14 & - \\
Soybean meal & 6 & - \\
Molasses, dry & 4 &
\end{tabular}


container and weighed. Pellet bulk density was obtained from the ratio of measured mass of the sample in the container to the volume of the container [19] [20]. Density of an individual pellet was determined using procedures described by Mahapatra et al. [20].

\subsubsection{Evaluation of Pellet Hardness}

Hardness represents the rigidity of pellets and may be expressed in terms of firmness. Hardness can also be related to the chewability (chewing of feed pellets between animal teeth) or palatability of pellets [20] [23] [30]. The hardness of Paulownia pellets was determined by a texture analyzer (Model \# TA-XT2i, Stable Micro Systems, Surrey, UK) using procedures outlined by Mahapatra et al. [20]. Ten randomly selected pellets were used in this test.

\subsection{Statistical Analysis}

Paulownia leaf pellet data were analyzed using SAS 9.4 system (SAS Institute Inc., Cary, NC, USA) and Microsoft Excel to determine least squared means and standard error, with treatments differences determined using the least significant difference test $(L S D)(p<0.05)$. Data for plant height and chemical analysis were analyzed using analysis of variance (ANOVA) in Microsoft Excel (Microsoft Corp., Seattle, WA, USA). The treatment means were analyzed using Tukey's post-hoc mean separation test with the least significance difference between different plots and months with results at $\mathrm{p}<0.05$ level.

\section{Results and Discussion}

\subsection{Paulownia Growth under Middle Georgia Conditions}

Paulownia trees showed a steady increase in diameter at breast height (DBH) with respect to overall tree height over a three-year period in the timber plot (Figure 2(A)). Analysis of data obtained for $P$. elongata shows active growth leading to increase in height as well as girth. As per our observation, with the onset of spring the trees acquire height first which is distinct and later in the season biomass begins accumulating in the trunk. The equation for $P$. elongata shows a high amount of variance, with an $\mathrm{R}^{2}$ value of 0.49 (Figure 2(A)). Currently, trees have completed eight years of growth and on average are 12-15 m tall in bioenergy and timber plots. Paulownia Demonstration Plot studies established that $P$. elongata can be successfully grown in the middle Georgia conditions (Figures 1(A)-(C)). Figures $1(\mathrm{~A})-(\mathrm{C})$ show tree growth at establishment stage, after three years, and coppicing nature once the main trunk is harvested. Data on height and $\mathrm{DBH}$ were obtained from non-coppiced trees that were present in the timber plot.

Paulownia trees in timber plot showed a steady increase in diameter at breast height $(\mathrm{DBH})$ with respect to overall tree height over a three-year period (Figure 2(A)). These results support our premise that Paulownia is a fast growing tree, and that the trees planted at the FVSU have thrived well in the 


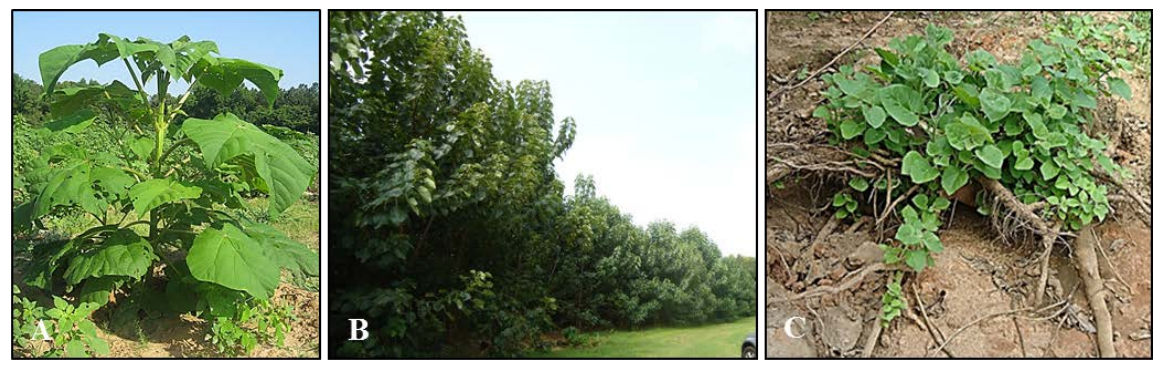

Figure 1. Paulownia Demonstration Plot at FVSU experimental farm. (A) Eight week old P. elongata planting; (B) Trees after three years of growth; and (C) After harvesting a tree extensive network of new shoots.

middle Georgia climate. They also support the general consensus that Paulownia accumulates a large amount of biomass in a short period of time. Observations for the tree growth patterns in the first few years of growth show that it accumulates a lot more biomass after the initial season of growth.

\subsection{Chemical Analysis}

\subsubsection{Percent Ash and Mineral Analysis}

Percent ash is the percentage of minerals present in Paulownia and ranged from $6 \%-9 \%$ throughout the growing season (Figure 2(B)). There were no significant differences between each plot nor between samples taken each month. The mineral analysis was conducted on ground leaf-blade tissue that was collected between April to November 2011 (Table 2) and showed Ca concentrations ranging from $0.72 \%$ to $2.48 \%$, $\mathrm{P}$ from $0.15 \%$ to $0.26 \%$, $\mathrm{K}$ from $0.90 \%$ to $1.90 \%$, $\mathrm{Mg}$ from $0.29 \%$ to $0.47 \%, \mathrm{Zn}$ from 6.96 to $29.97 \mathrm{ppm}$, and Mn concentrations from 30.67 to $60.99 \mathrm{ppm}$. Leaf samples collected from bioenergy and timber plots recorded $7.99 \%$ and $7.34 \%$ for total ash content, respectively, that averaged as total ash content in leaves for both plots at $7.67 \%$. The micro-mineral requirements for goat $\left(\mathrm{mg}^{\mathrm{kg}} \mathrm{kg}^{-1}\right)$ are $\mathrm{Cu}(1-23), \mathrm{Zn}(10-50), \mathrm{Mn}(20-40), \mathrm{Fe}$ (30 - 100), while requirements for the macro-minerals (\%) $\mathrm{K}$ and $\mathrm{Mg}$ are 0.5 and 0.2 , respectively [13]. Calcium and $\mathrm{P}$ values need to be $0.6 \%$ and $0.3 \%$, respectively, to support young growing kids or does in early lactation [31]. The mineral profile for $P$. elongata indicated a high potential for the leaves tested, meeting or exceeding most of these requirements. In addition, concentration of heavy metals in Paulownia leaves ( $\mathrm{Cu}, \mathrm{Cd}, \mathrm{Pb}, \mathrm{Mn}, \mathrm{Zn}$ ) do not exceed published critical and toxic levels [32]. The mineral concentrations found in Paulownia leaves in the current investigation compare favorably with forage analyses that have been conducted on genus Paulownia in previous literature [13]. Also, the mineral profile for $P$. elongata compares well to that of other leguminous browse species Albizia julibrissin, Glelditsia triacanthos and Robinia pseudoacacia [13].

\subsubsection{Neutral Detergent Fiber (NDF)}

The NDF concentrations for the $P$. elongata leaves collected from April to November 2011 ranged from $29 \%$ - 54\%, with generally higher values ( $40 \%-50 \%)$ 


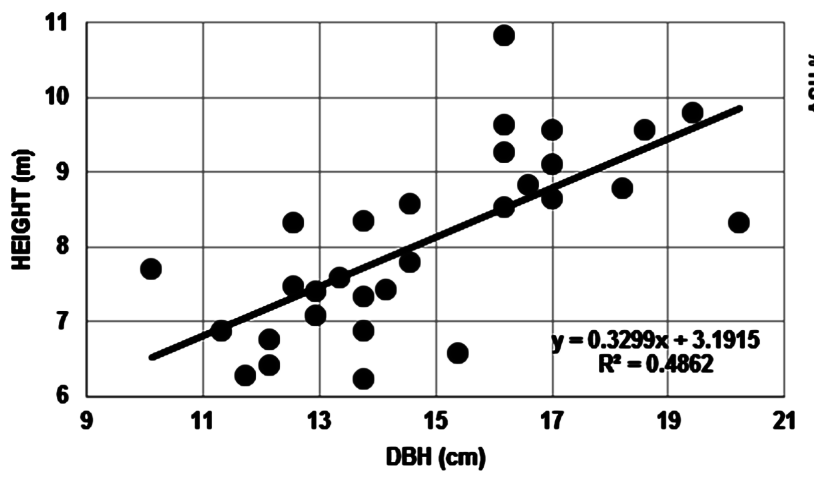

(A)

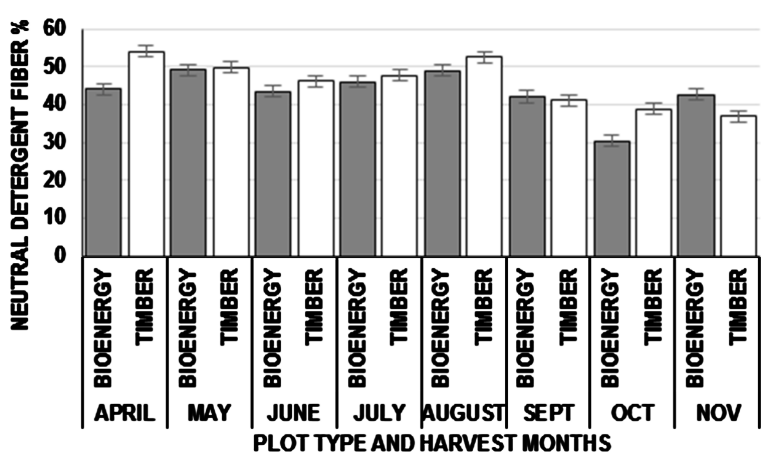

(C)

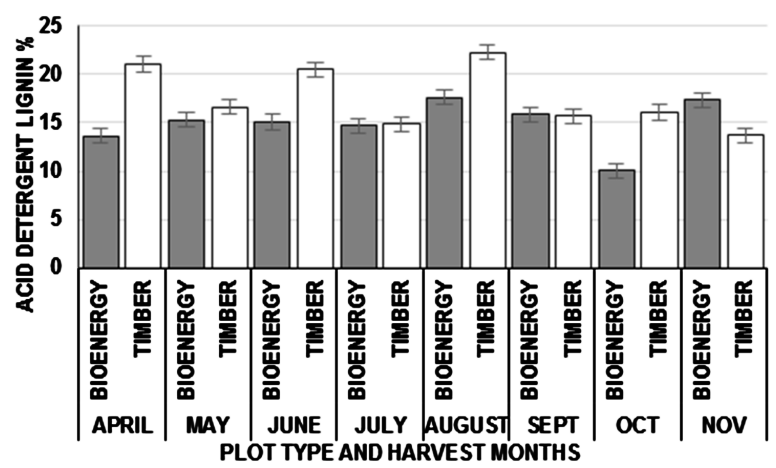

(E)

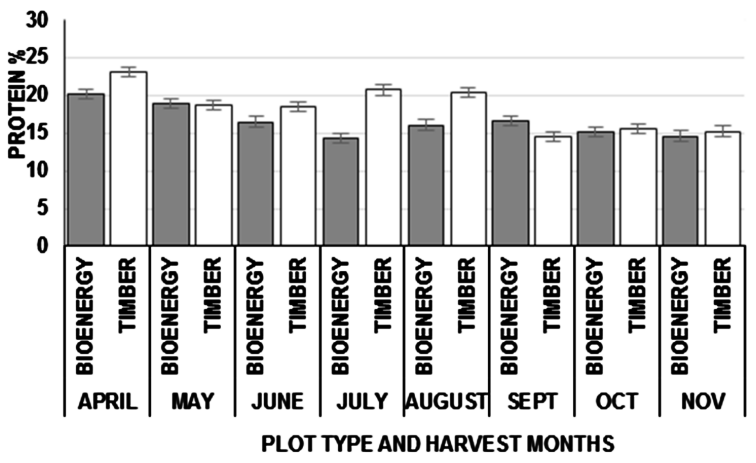

(G)

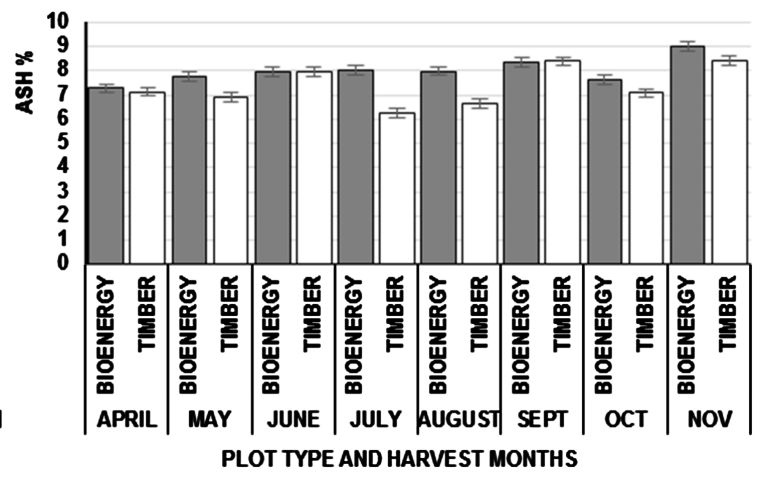

(B)

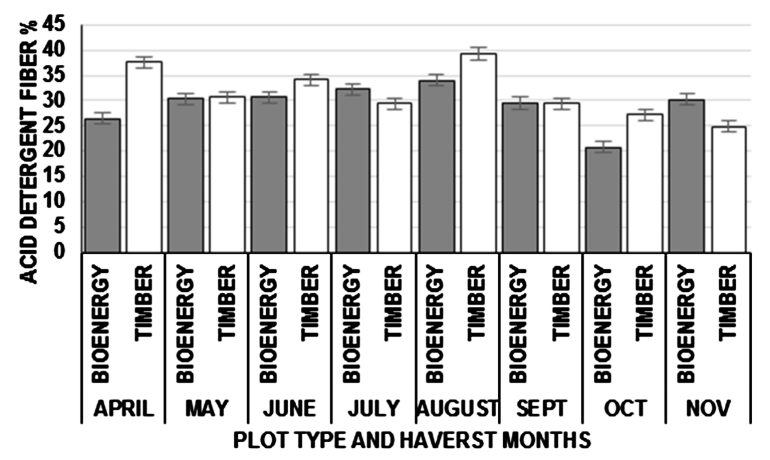

(D)

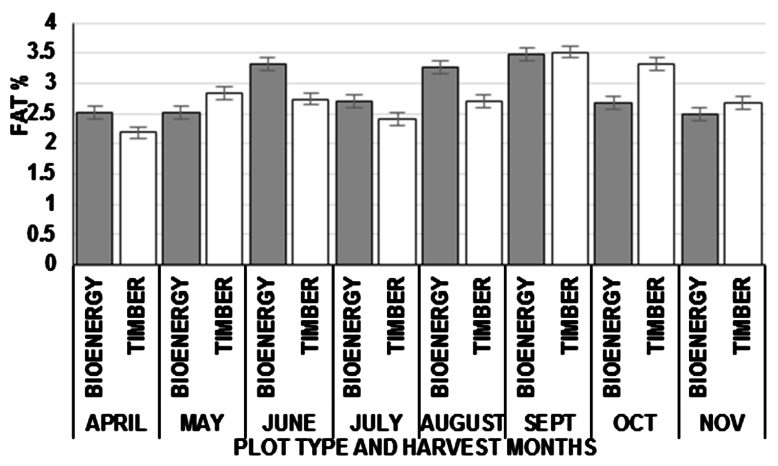

(F)

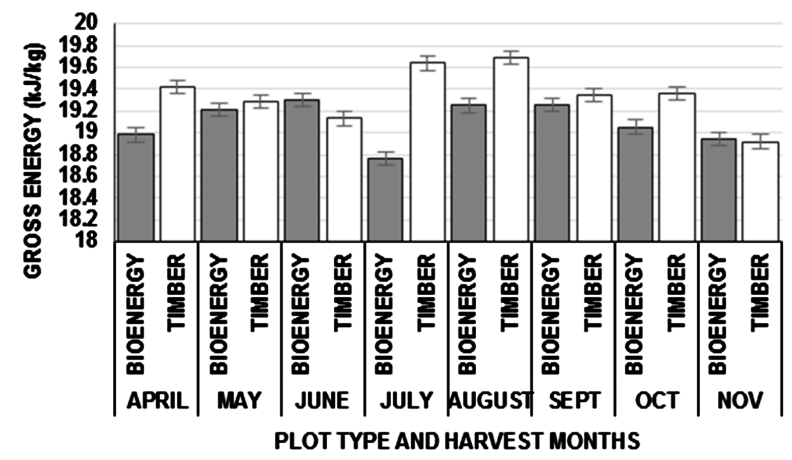

(H)

Figure 2. Growth measurement and leaf analysis of Paulownia elongata. (A) Thirty months old trees of $P$. elongata growing at the Paulownia Demonstration Plot at FVSU experimental farm. Average concentrations (\%) of nutrients in $P$. elongata leaves harvested during the months from April-November; (B) Ash; (C) Neutral Detergent Fiber; (D) Acid Detergent Fiber; (E) Acid Detergent Lignin; (F) Fat; (G) Crude Protein; and (H) Gross Energy. 
Table 2. Mineral Analysis estimation of Paulownia leaves collected at monthly intervals.

\begin{tabular}{|c|c|c|c|c|c|c|c|c|c|c|c|c|c|c|c|c|c|c|}
\hline \multirow{2}{*}{ Sample ${ }^{1}$} & \multicolumn{6}{|c|}{ Percentage } & \multicolumn{12}{|c|}{ ppm } \\
\hline & $\mathrm{Ca}$ & $\mathrm{K}$ & $\mathrm{Mg}$ & $\mathrm{N}$ & $\mathrm{P}$ & $\mathrm{S}$ & $\mathrm{Al}$ & B & $\mathrm{Cd}$ & $\mathrm{Cr}$ & $\mathrm{Cu}$ & $\mathrm{Fe}$ & $\mathrm{Mn}$ & Mo & $\mathrm{Na}$ & $\mathrm{Ni}$ & $\mathrm{Pb}$ & $\mathrm{Zn}$ \\
\hline APR B-1 & 0.72 & 1.74 & 0.29 & 3.10 & 0.21 & 0.16 & 63.0 & 32.68 & $<0.40$ & $<1.00$ & 10.21 & 91.9 & 30.67 & $<1.00$ & $<2.00$ & $<2.00$ & $<5.00$ & 29.97 \\
\hline APR B-3 & 0.82 & 1.90 & 0.32 & 3.23 & 0.23 & 0.17 & 82.6 & 33.49 & $<0.40$ & $<1.00$ & 10.00 & 94.4 & 33.28 & $<1.00$ & $<2.00$ & $<2.00$ & $<5.00$ & 26.56 \\
\hline APR T-1 & 0.91 & 1.88 & 0.30 & 3.70 & 0.25 & 0.20 & 80.9 & 44.68 & $<0.40$ & $<1.00$ & 10.08 & 90.4 & 42.01 & $<1.00$ & $<2.00$ & $<2.00$ & $<5.00$ & 21.20 \\
\hline APR T-2 & 0.88 & 1.79 & 0.30 & 3.63 & 0.25 & 0.19 & 98.1 & 44.93 & $<0.40$ & $<1.00$ & 10.33 & 96.7 & 41.12 & $<1.00$ & $<2.00$ & $<2.00$ & $<5.00$ & 23.55 \\
\hline MAY B-2 & 1.17 & 1.72 & 0.36 & 3.12 & 0.19 & 0.17 & 155.4 & 41.28 & $<0.40$ & $<1.00$ & 8.71 & 131.1 & 40.36 & 1.03 & $<2.00$ & $<2.00$ & $<5.00$ & 18.54 \\
\hline MAY B-3 & 1.24 & 1.76 & 0.37 & 3.05 & 0.20 & 0.17 & 140.0 & 39.87 & $<0.40$ & $<1.00$ & 7.76 & 125.3 & 38.58 & $<1.00$ & $<2.00$ & $<2.00$ & $<5.00$ & 18.25 \\
\hline MAY T-1 & 0.97 & 1.59 & 0.35 & 3.11 & 0.19 & 0.17 & 138.8 & 35.29 & $<0.40$ & $<1.00$ & 8.13 & 114.2 & 35.73 & $<1.00$ & $<2.00$ & $<2.00$ & $<5.00$ & 19.00 \\
\hline MAY T-3 & 1.01 & 1.59 & 0.35 & 3.09 & 0.18 & 0.17 & 145.1 & 37.32 & $<0.40$ & $<1.00$ & 6.16 & 119.2 & 33.75 & $<1.00$ & $<2.00$ & $<2.00$ & $<5.00$ & 16.83 \\
\hline JUN B-1 & 1.45 & 1.31 & 0.43 & 2.75 & 0.16 & 0.16 & 164.0 & 48.27 & $<0.40$ & $<1.00$ & 5.43 & 122.2 & 38.34 & $<1.00$ & $<2.00$ & $<2.00$ & $<5.00$ & 15.02 \\
\hline JUN B-2 & 1.56 & 1.51 & 0.39 & 2.63 & 0.17 & 0.15 & 163.3 & 57.95 & $<0.40$ & $<1.00$ & 5.21 & 131.4 & 47.33 & $<1.00$ & $<2.00$ & $<2.00$ & $<5.00$ & 12.04 \\
\hline JUN T-1 & 1.24 & 1.63 & 0.42 & 3.22 & 0.23 & 0.18 & 174.1 & 54.82 & $<0.40$ & $<1.00$ & 9.96 & 188.9 & 44.16 & $<1.00$ & $<2.00$ & 3.44 & $<5.00$ & 22.55 \\
\hline JUN T-3 & 1.26 & 1.62 & 0.42 & 3.10 & 0.22 & 0.18 & 145.1 & 54.15 & $<0.40$ & $<1.00$ & 8.61 & 128.9 & 43.67 & $<1.00$ & $<2.00$ & $<2.00$ & $<5.00$ & 17.65 \\
\hline JUL B-2 & 1.80 & 1.09 & 0.47 & 2.39 & 0.16 & 0.15 & 201.5 & 55.34 & $<0.40$ & $<1.00$ & 6.35 & 155.2 & 42.53 & 1.03 & 7.98 & $<2.00$ & $<5.00$ & 10.48 \\
\hline JUL B-3 & 1.88 & 1.22 & 0.44 & 2.26 & 0.17 & 0.14 & 190.8 & 61.35 & $<0.40$ & $<1.00$ & 6.70 & 142.6 & 42.93 & 1.17 & 5.83 & $<2.00$ & $<5.00$ & 9.87 \\
\hline JUL T-1 & 1.10 & 1.29 & 0.37 & 3.55 & 0.26 & 0.19 & 96.0 & 51.09 & $<0.40$ & $<1.00$ & 10.31 & 88.0 & 36.54 & 1.10 & 17.86 & $<2.00$ & $<5.00$ & 21.45 \\
\hline JUL T-2 & 1.19 & 1.36 & 0.39 & 3.28 & 0.25 & 0.18 & 98.9 & 53.13 & $<0.40$ & $<1.00$ & 9.56 & 83.6 & 38.32 & 1.31 & 11.03 & $<2.00$ & $<5.00$ & 20.53 \\
\hline AUG B-1 & 1.79 & 1.04 & 0.45 & 2.89 & 0.21 & 0.17 & 167.8 & 59.49 & $<0.40$ & $<1.00$ & 7.74 & 135.5 & 44.23 & 1.49 & $<2.00$ & $<2.00$ & $<5.00$ & 13.92 \\
\hline AUG B-2 & 1.93 & 0.90 & 0.46 & 2.42 & 0.17 & 0.15 & 184.0 & 60.47 & $<0.40$ & $<1.00$ & 5.25 & 132.5 & 43.57 & 1.24 & $<2.00$ & $<2.00$ & $<5.00$ & 10.05 \\
\hline AUG T-2 & 1.27 & 1.17 & 0.37 & 3.39 & 0.26 & 0.19 & 133.2 & 64.50 & $<0.40$ & 1.21 & 8.59 & 124.9 & 36.44 & 1.03 & $<2.00$ & $<2.00$ & $<5.00$ & 13.71 \\
\hline AUG T-3 & 1.36 & 1.14 & 0.38 & 3.31 & 0.24 & 0.18 & 135.4 & 67.63 & $<0.40$ & $<1.00$ & 8.47 & 125.7 & 39.13 & $<1.00$ & $<2.00$ & $<2.00$ & $<5.00$ & 15.09 \\
\hline SEP B-2 & 1.95 & 1.04 & 0.47 & 2.61 & 0.17 & 0.16 & 174.3 & 57.44 & $<0.40$ & $<1.00$ & 4.79 & 126.4 & 46.48 & 1.27 & $<2.00$ & $<2.00$ & $<5.00$ & 15.98 \\
\hline SEP B-3 & 1.89 & 1.01 & 0.43 & 2.55 & 0.17 & 0.16 & 173.9 & 65.37 & $<0.40$ & $<1.00$ & 4.02 & 123.2 & 47.07 & 1.10 & $<2.00$ & $<2.00$ & $<5.00$ & 9.94 \\
\hline SEP T-2 & 2.08 & 0.95 & 0.43 & 2.19 & 0.16 & 0.14 & 221.8 & 80.64 & $<0.40$ & $<1.00$ & 4.38 & 125.0 & 60.99 & $<1.00$ & $<2.00$ & $<2.00$ & $<5.00$ & 8.67 \\
\hline SEP T-3 & 2.01 & 0.92 & 0.44 & 2.24 & 0.16 & 0.14 & 222.6 & 81.55 & $<0.40$ & $<1.00$ & 4.77 & 122.8 & 58.74 & $<1.00$ & $<2.00$ & $<2.00$ & $<5.00$ & 6.96 \\
\hline OCT B-1 & 2.00 & 0.82 & 0.39 & 2.35 & 0.16 & 0.15 & 138.1 & 56.89 & $<0.40$ & $<1.00$ & 6.41 & 97.2 & 44.21 & 1.17 & $<2.00$ & $<2.00$ & $<5.00$ & 12.86 \\
\hline OCT B-2 & 1.89 & 0.97 & 0.37 & 2.31 & 0.17 & 0.15 & 121.2 & 56.33 & $<0.40$ & $<1.00$ & 4.48 & 83.2 & 42.65 & 1.06 & $<2.00$ & $<2.00$ & $<5.00$ & 10.90 \\
\hline OCT T-2 & 1.50 & 0.94 & 0.31 & 2.48 & 0.19 & 0.14 & 147.7 & 75.63 & $<0.40$ & $<1.00$ & 4.23 & 84.1 & 40.07 & $<1.00$ & $<2.00$ & $<2.00$ & $<5.00$ & 11.68 \\
\hline OCT T-3 & 1.74 & 1.13 & 0.35 & 2.42 & 0.23 & 0.15 & 158.4 & 85.15 & $<0.40$ & $<1.00$ & 4.09 & 92.8 & 45.54 & $<1.00$ & $<2.00$ & $<2.00$ & $<5.00$ & 10.87 \\
\hline NOV B-1 & 2.48 & 1.03 & 0.42 & 2.23 & 0.15 & 0.16 & 168.5 & 64.37 & $<0.40$ & $<1.00$ & 6.68 & 94.7 & 47.96 & 1.17 & $<2.00$ & $<2.00$ & $<5.00$ & 10.26 \\
\hline NOV B-2 & 2.35 & 1.06 & 0.38 & 2.27 & 0.16 & 0.15 & 160.5 & 62.04 & $<0.40$ & $<1.00$ & 4.29 & 92.9 & 47.49 & $<1.00$ & $<2.00$ & $<2.00$ & $<5.00$ & 12.04 \\
\hline NOV T-2 & 2.02 & 1.03 & 0.35 & 2.35 & 0.17 & 0.16 & 174.8 & 81.73 & $<0.40$ & $<1.00$ & 4.38 & 100.5 & 47.92 & $<1.00$ & $<2.00$ & $<2.00$ & $<5.00$ & 9.20 \\
\hline NOV T-3 & 2.17 & 1.07 & 0.36 & 2.29 & 0.18 & 0.15 & 175.6 & 86.90 & $<0.40$ & $<1.00$ & 5.02 & 105.0 & 50.43 & $<1.00$ & $<2.00$ & $<2.00$ & $<5.00$ & 12.36 \\
\hline
\end{tabular}

${ }^{1}$ In sample designation, $\mathrm{B}=$ bioenergy plot; $\mathrm{T}=$ timber plot. 
in the spring and summer months (April-August), and lower values (30\% - 40\%) during autumn (September-November; Figure 2(C)). Neutral detergent fiber quantity remained more or less same during April to November averaging $44.68 \%$.

These values are generally higher and more variable than the NDF values reported for P. tomentosa, P. fortunei, and P. elongata grown in North Carolina, which ranged from $38.2 \%$ to $44.6 \%$ [13]. This may be related to differences in local growing conditions between middle Georgia ( $\left.32^{\circ} 32^{\prime} 27.834^{\prime \prime} \mathrm{N},-83^{\circ} 53^{\prime} 45.8844^{\prime \prime} \mathrm{W}\right)$ and northern North Carolina ( $\left.35^{\circ} 47^{\prime} 04.791 " \mathrm{~N},-78^{\circ} 40^{\prime} 55.541^{\prime \prime} \mathrm{W}\right)$. At a lower latitude, seasonal temperatures are generally higher in middle Georgia (thirty year annual temperatures average $17.0^{\circ} \mathrm{C}$ ) than in North Carolina (thirty year annual temperatures average $16.1^{\circ} \mathrm{C}$ ), possibly leading to higher fiber development in Georgia-produced trees during summer [33].

\subsubsection{Acid Detergent Fiber (ADF)}

The range for ADF in our leaf samples was 18\% - 39\% (Figure 2(D)). The acid detergent fiber value for both the plots was same at $30.43 \%$. Acid detergent fiber values in our studies are generally more variable than the values previously reported for Paulownia species, which were $33.9 \%, 31.1 \%$, and $31.9 \%$ for P. tomentosa, $P$. fortunei, and P. elongata, respectively [13]. The ADF values for Paulownia leaves in our study show a similar seasonal pattern as NDF, with higher concentrations in spring and summer months and generally lower values in autumn (Figure 2(D)).

\subsubsection{Acid Detergent Lignin (ADL)}

The percentage of ADL in Paulownia leaves ranged from 10\% - 22\% in the current study, with most of the values in the $15 \%-18 \%$ range (Figure $2(E)$ ). The percent lignin content in various Paulownia species ( $P$. tomentosa, $P$. fortunei, and $P$. elongata) ranged from $16 \%$ to $22.3 \%$, lowest lignin content being recorded in P. elongata [13].

\subsubsection{Percent Fat}

Fat content ranged from $1.9 \%$ to $3.8 \%$ for $P$. elongata leaves that were collected from April to November (Figure 2(F)). Average fat content for the leaves collected from bioenergy and timber plot was $2.87 \%$ and $2.80 \%$, respectively. On an average, the fat content in Paulownia leaves recorded was $2.83 \%$.

\subsubsection{Crude Protein (CP)}

For $P$. elongata growing in the middle Georgia climate, crude protein content of leaves averaged at $17.49 \%$. Crude protein levels of $P$. elongata leaves remained fairly stable throughout the growing season in Georgia (April to November). Crude protein values need to be near or above 14\% [13], when pertaining to kid nutrition and the early lactation period of does. Paulownia $\mathrm{CP}$ values met or exceeded these nutritional requirements and ranged from 14.3\% - 23.3\% (Figure 2(G)). These values are slightly lower than values obtained by Mueller [13] for $P$. 
tomentosa, $P$. fortunei, and $P$. elongata. Crude protein levels of $P$. elongata leaves remained fairly stable throughout the growing season in Georgia (April to November), which may increase the potential use of these species as livestock fodder during periods of high quality feed shortage. This generally occurs in the late summer/early fall period in the southeastern United States when perennial warm-season grasses, such as Bermuda grass (Cynodon dactylon) and Bahia grass (Paspalum notatum), become reproductive and rapidly lose their feed value.

\subsubsection{Gross Energy}

The total energy content of Paulownia leaf samples collected over April to November ranged between $18.6-19.6 \mathrm{~kJ} \cdot \mathrm{kg}^{-1}$, averaging at $19.22 \mathrm{~kJ} \cdot \mathrm{kg}^{-1}$ (Figure $2(\mathrm{H})$ ). The total energy content of Paulownia leaf samples ranged between 18.6 $19.6 \mathrm{~kJ} \cdot \mathrm{kg}^{-1}$, averaging at $19.22 \mathrm{~kJ} \cdot \mathrm{kg}^{-1}$ (Figure $2(\mathrm{H})$ ). It does not indicate the digestibility of the food. Further experimentation will be required to address digestibility and nutritional benefits of Paulownia leaf based formulations.

The total digestible nutrients (TDN) consist of digestible fiber, protein, lipid, and carbohydrate contents. A general idea regarding TDN of Paulownia leaves can be obtained by employing formula used for alfalfa

$$
\mathrm{TDN}=96.35-(\% \mathrm{ADF} \times 1.15)
$$

Using this formula a TDN value of 61.36 in obtained considering average $\mathrm{ADF} \%$ at 30.43 . This value is in recommended range.

\subsection{Pellet Dimensions and Bulk Properties}

\subsubsection{Pellet Dimensions}

Measured linear dimensions of $75 \%$ and $95 \%$ Paulownia pellets are presented in Table 3. Data presented are the mean of measurements made on 10 pellets of each type. The length of pellets varied from 32 to $39 \mathrm{~mm}$ and 30 to $39 \mathrm{~mm}$ for the $75 \%$ and $95 \%$ Paulownia pellets, respectively. Average length of $75 \%$ pellets was greater than the 95\% Paulownia pellets $(\mathrm{p}<0.05)$. The pellet diameter ranged from 3.54 to $3.6 \mathrm{~mm}$, and no significant difference was observed between 75\% and 95\% Paulownia pellets.

Table 3. Mean physical properties of $P$. elongata leaf pellets $(n=10)$.

\begin{tabular}{ccc}
\hline Properties & \multicolumn{2}{c}{ Mean values \pm S.E. } \\
\hline Paulownia $\rightarrow$ & $75 \%$ & $95 \%$ \\
\hline Length, $\mathrm{mm}$ & $36.4 \pm 0.72^{\mathrm{a}}$ & $32.77 \pm 1^{\mathrm{b}}$ \\
Diameter, $\mathrm{mm}$ & $3.59 \pm 0.01^{\mathrm{a}}$ & $3.59 \pm 0.01^{\mathrm{a}}$ \\
Unit weight, $\mathrm{g}$ & $0.72 \pm 0.06^{\mathrm{a}}$ & $0.71 \pm 0.01^{\mathrm{a}}$ \\
Unit density, $\mathrm{kg} \cdot \mathrm{m}^{-3}$ & $1958.05 \pm 42.8^{\mathrm{a}}$ & $2164.96 \pm 66.51^{\mathrm{b}}$ \\
Bulk density, $\mathrm{kg} \cdot \mathrm{m}^{-3}$ & $557.21 \pm 7.56^{\mathrm{a}}$ & $596.1 \pm 7.14^{\mathrm{b}}$ \\
Hardness, $\mathrm{N}$ & $31.65 \pm 0.23^{\mathrm{a}}$ & $34.36 \pm 0.23^{\mathrm{b}}$
\end{tabular}

Means in the same row sharing a common letter are not significantly different at $\mathrm{p}<0.05$. 


\subsubsection{Bulk Properties}

Unit weight of pellets ranged from 0.69 to $0.74 \mathrm{~g}$ and from 0.68 to $0.74 \mathrm{~g}$ for the $75 \%$ and $95 \%$ Paulownia pellets, respectively, and did not show any significant difference $(p>0.05)$. The bulk density of pellets ranged from 546.94 to 571.96 $\mathrm{kg} \cdot \mathrm{m}^{-3}$ and with 584.08 to $608.74 \mathrm{~kg} \cdot \mathrm{m}^{-3}$, for the $75 \%$ and $95 \%$ Paulownia pellets, respectively, and there were significant differences $(\mathrm{p}<0.05)$ between the $75 \%$ and $95 \%$ pellets, with greater bulk density in the $95 \%$ Paulownia pellets (Table 3). The unit density ranged from 1731.86 to $2261.02 \mathrm{~kg} \cdot \mathrm{m}^{-3}$ and from 1778.97 to $2388.97 \mathrm{~kg} \cdot \mathrm{m}^{-3}$ for the $75 \%$ and $95 \%$ Paulownia pellets, respectively. Average unit density of $95 \%$ Paulownia pellets was higher than the unit density of $75 \%$ Paulownia pellets $(\mathrm{p}<0.05)$ (Table 3 ). A bulk density range of 578.3 to 643.2 $\mathrm{kg} \cdot \mathrm{m}^{-3}$ for dehydrated alfalfa pellets [34] and from 554.8 to $670.9 \mathrm{~kg} \cdot \mathrm{m}^{-3}$ for canola meal pellets have been reported [18].

\subsubsection{Pellet Hardness}

Pellet hardness ranged from $30.46 \mathrm{~N}$ to $32.67 \mathrm{~N}$ in case of $75 \%$ Paulownia leaf pellets and $33.22 \mathrm{~N}$ to $35.73 \mathrm{~N}$ for 95\% Paulownia pellets (Table 3), with significantly higher hardness values $(\mathrm{p}<0.05)$ for the $95 \%$ pellets. The estimated digestible dry matter (DDM) for Paulownia based feed pellets is $65.20 \%$. The dry matter intake (DMI) value is $2.69 \%$ for Paulownia based feed pellets. The relative feed value (RFV) was 135.74 .

Greater pellet hardness, bulk density, and unit density as the percentage Paulownia leaf increased should be advantageous to feed manufacturers and producers using this product, with reduced volume of storage required for pellet storage and increased pellet durability during packaging, transportation, and storage [18] [35].

The estimated digestible dry matter (DDM) for Paulownia based feed pellets is $65.20 \%$. This value was derived as per Schroeder [36]. The dry matter intake (DMI) value is $2.69 \%$ for Paulownia based feed pellets. The value is important since it is directly correlated to milk production in animals. Though many factors do affect calculation of DMI, such as body mass of a ruminant, and an amount of forage, the variability in NDF percent plays a crucial role. The relative feed value (RFV) was 135.74, which is considered high. Any forage higher than 100 value is considered a good quality forage.

A comparative account of important nutrient indicators has been presented in Table 4. A comparison with alfalfa, hay, and mulberry [37] [38] [39] reveals that Paulownia leaf based feed has a balanced nutrient profile and can be used to supplement already existing feedstock.

\section{Conclusion}

Livestock production is increasingly dependent on factors like increasing demands for animal products and paucity of protein rich feed raw materials supplies. Fodder trees and shrubs have always played a significant role in feeding livestock. 
Table 4. A comparative account of important nutrient indicators in popular feed sources with $P$. elongata leaf analysis.

\begin{tabular}{ccccc}
\hline & Alfalfa (Dairy quality) & Grass (Hay) & Mulberry & Paulownia \\
\hline CP \% & 18 & 8.44 & 18.9 & 17.20 \\
TDN \% & 60 & 53 & 75.30 & 61.36 \\
Crude Fiber \% (NDF) & 43.45 & 31.4 & 31.1 & 44.68 \\
ADL (Lignin) \% & 8.8 & 2.9 & 5.5 & 15.16 \\
P \% & 0.22 & 0.19 & 0.21 & 0.20 \\
Ca \% & 1.41 & 0.54 & 2.98 & 1.55 \\
Mg \% & 0.33 & 0.12 & 5.28 & 2.80 \\
K \% & 2.52 & 1.33 & 15.93 & 1.29 \\
Zn (mg. $\mathrm{kg}^{-1}$ ) & 0.92 & 21 & 26.8 & 15.25 \\
\hline
\end{tabular}

Trees and shrubs support animal feeding, especially as a protein supplier where the available grazing is not adequate for the maintenance requirement of animals. Perennials trees are able to tolerate prolonged periods of water shortage than grasses. Our studies provide evidence to the suitability of growing $P$. elongata trees as a multipurpose crop in middle Georgia, and analysis of Paulownia leaves indicates its potential use as livestock forage throughout the growing season in this region (April to November). With more provenance trials in other areas of the southeastern United States with a similar climate, suitability of Paulownia tree can be further strengthened either through direct browsing or feeding in pellet form. In the regions with dry autumns, there is a potential to collect the leaves and process them to be baled, make pellets, or use for silage. If Paulownia is grown as a dedicated fodder tree only, then it would be a better idea to coppice and allow growing multiple trunks. This way shoots can be pruned at a convenient height and harvested as required. Further, it has been suggested that Paulownia leaves and other parts are rich in medicinal components and antioxidant activity that may impart additional health benefits to the animal. More work (feeding/browsing trials) with this multipurpose tree is warranted to determine its palatability and nutritional potential for grazing/browsing livestock.

\section{Acknowledgements}

This research has been funded through an Evans Allen grant (GEOX 5213, PI-NJ). We appreciate technical assistance provided by Jolethia Ogelsby and Vicki Owen.

\section{References}

[1] Cassidy, E.S., West, P.C., Gerber, J.S. and Foley, J.A. (2013) Redefining Agricultural Yields: From Tonnes to People Nourished Per Hectare. Environmental Research Letters, 8, 1-8. https://doi.org/10.1088/1748-9326/8/3/034015

[2] Lefroy, S.C., Dann, P.R., Wildin, J.I., Wesley Smith, R.N. and McGowan, A.A. (1992) Trees and Shrubs as Source of Fodder in Australia. Agroforestry Systems, 20, 


\section{7-139. https://doi.org/10.1007/BF00055307}

[3] Jiang, Z., Gao, L., Fang, Y. and Sun, X. (1994) Analysis of Paulownia Intercropping Types and Their Benefits in Woyang County of Anhui Province. Forest Ecology and Management, 67, 329-337. https://doi.org/10.1016/0378-1127(94)90027-2

[4] Topps, J.H. (1992) Potential Composition and Use of Legume Shrubs and Trees as Fodders for Livestock in the Tropics. Journal of Agriculture Science, 118, 1-8. https://doi.org/10.1017/S0021859600067940

[5] Joshee, N. (2012) A Multipurpose Tree for Rapid Lignocellulosic Biomass Production. In: Kole, C., Joshi, C.P. and Shonnard, D., Eds., Handbook of Bioenergy Crop Plants, Taylor and Francis, Milton Park, Abingdon-on-Thames, 671-686.

[6] Basu, C., Joshee, N., Gazelian, T., Vaidya, B.N., Saditkit, A., Hemmati, H. and Perry, Z.D. (2015) Cross-Species PCR and Field Studies on Paulownia elongata: A Potential Bioenergy Crop. Bioethanol, 2, 1-15.

[7] Snow, W.A. (2015) Ornamental, Crop, or Invasive? The History of the Empress Tree (Paulownia) in the USA. Forests, Trees and Livelihoods, 24, 85-96.

https://doi.org/10.1080/14728028.2014.952353

[8] Li, P. and Oda, J. (2007) Flame Retardancy of Paulownia Wood and Its Mechanism. Journal of Materials Science, 42, 8544-8550. https://doi.org/10.1007/s10853-007-1781-9

[9] Zhu, Z.H., Chao, C.J., Lu, X.Y. and Xiong, Y.G. (1986) Paulownia in China: Cultivation and Utilization. Asian Network for Biological Sciences, Republic of Singapore and International Development Research Centre, Canada.

[10] Vaughn, S.F., Dinelli, F., Tisserat, B., Joshee, N., Vaughan, M.M. and Peterson, S.C. (2015) Creeping Bentgrass Growth in Sand-Based Root Zones with or without Biochar. Scientia Horticulturae, 197, 592-596. https://doi.org/10.1016/j.scienta.2015.10.021

[11] Yadav, N.K., Vaidya, B.N., Henderson, K., Lee, J.F., Stewart, W.M., Dhekney, S.A. and Joshee, N. (2013) A Review of Paulownia Biotechnology: A Short-Rotation, Fast Growing Multipurpose Bioenergy Tree. American Journal of Plant Sciences, 4, 2070-2082. https://doi.org/10.4236/ajps.2013.411259

[12] He, T., Vaidya, B.N., Perry, Z.D., Parajuli, P. and Joshee, N. (2016) Paulownia as a Medicinal Tree: Traditional Uses and Current Advances. European Journal of Medicinal Plant, 14, 1-15. https://doi.org/10.9734/EJMP/2016/25170

[13] Mueller, J.P., Lunginbuhl, J.M. and Bergmann, B.A. (2001) Establishment and Early Growth Characteristics of Six Paulownia Genotypes for Goat Browse in Raleigh, NC, USA. Agroforestry Systems, 52, 63-72. https://doi.org/10.1023/A:1010641602384

[14] Salem, A.Z.M., Salem, M.Z.M., El-Adawy, M.M. and Robinson, P.H. (2005) Nutritive Evaluations of Some Browse Tree Foliages during the Dry Season: Secondary Compounds, Feed Intake and in Vivo Digestibility in Sheep and Goats. Animal Feed Science and Technology, 127, 251-267. https://doi.org/10.1016/j.anifeedsci.2005.09.005

[15] Silanikove, N. (2000) Interrelationship between Water, Food and Digestible Energy Intake in Desert and Temperate Goats. Appetite, 12, 163-170. https://doi.org/10.1016/0195-6663(89)90114-1

[16] Salem, A.Z.M., Gonzalez, J.S., Lopez, S. and Ranillas, M.J. (2004) Feeding Behavior Patterns and Water Intake in Sheep and Goats Fed Alfalfa Hay Treated with Quebracho. Options Mediterranean, 59, 215-219.

[17] Bergmann, B.A., Rubin, A.R. and Campbell, C.R. (1997) Potential of Paulownia 
elongata Trees for Swine Waste Utilization. American Society of Agricultural Engineers, 40, 1733-1738. https://doi.org/10.13031/2013.21401

[18] White, N.D.G. and Jayas, D.S. (2001) Physical Properties of Canola and Sunflower Meal Pellets. Canadian Biosystems Engineering, 43, 349-352.

[19] Colley, Z., Fasina, O.O., Bransby, D. and Lee, Y.Y. (2006) Moisture Effect on the Physical Characteristics of Switchgrass Pellets. Transactions of the American Society of Agricultural and Biololgical Engineers, 49, 1845-1851. https://doi.org/10.13031/2013.22271

[20] Mahapatra, A.K., Harris, D.L., Durham, D.L., Lucas, S., Terrill, T.H., Kouakou, B. and Kannan, G. (2010) Effects of Moisture Change on the Physical and Thermal Properties of Sericea Lespedeza Pellets. International Agriculture Engineering Journal, 19, 23-29.

[21] Zainuddin, M.F., Rosnah, S., Mohdnoriznan, M. and Dahlan, I. (2014) Effect of Moisture Content on Physical Properties of Animal Feed Pellets from Pineapple Plant Waste. Agriculture and Agricultural Science Procedia, 2, 224-230. https://doi.org/10.1016/j.aaspro.2014.11.032

[22] Adapa, P.K., Tabil, L.G., Schoenau, G.J. and Sokhansanj, S. (2004) Pelleting Characteristics of Fractionated and Sun-Cured Dehydrate Alfalfa Grinds. Applied Engineering in Agriculture, 20, 813-820. https://doi.org/10.13031/2013.17714

[23] Adapa, P.K., Singh, A.K., Schoenau, G.J. and Tabil, L.G. (2006) Pelleting Characteristics of Fractionated Alfalfa Grinds: Hardness Models. Power Handling Process, 18, 1-6.

[24] Parsons, A.S., Buchanan, N.P., Blemings, K.P., Wilson, M.E. and Moritz, J.S. (2006) Effect of Corn Particle Size and Pellet Texture on Broiler Performance in the Growing Phase. Journal of Applied Poultry Research, 15, 245-255. https://doi.org/10.1093/japr/15.2.245

[25] Van Soest, P.J., Robertson, J.B. and Lewis, B.A. (1991) Methods for Dietary Fiber, Neutral Detergent Fiber, and Nonstarch Polysaccharides in Relation to Animal Nutrition. Journal of Dairy Science, 74, 3583-3597. https://doi.org/10.3168/jds.S0022-0302(91)78551-2

[26] AOAC (Association of Analytical Communities) (1984) Official Methods of Analysis. 14th Edition, Association of Official Analytical Chemists, Washington DC.

[27] Kirsten, W.J. (1979) Automated Methods for the Simultaneous Determination of Carbon, Hydrogen, Nitrogen and Sulfur, and Sulfur Alone in Organic and Inorganic Materials. Annals of Chemistry, 51, 1173-1179. https://doi.org/10.1021/ac50044a019

[28] Creed, J.T., Brockhoff, C.A. and Martin, T.D. (1994) US-EPA Method 200.8: Determination of Trace Elements in Waters and Wastes by Inductively Coupled Plasma-Mass Spectrometry. Revision 5.4 EMMC Version, EPA, Cincinnati.

[29] United States Environmental Protection Agency (1995) US-EPA Method 3052, Microwave Assisted Acid Digestion of Siliceous and Organically Based Matrices. EPA, Washington DC.

[30] Kaliyan, N. and Morey, R.V. (2006) Factors Affecting Strength and Durability of Densified Products. American Society of Agricultural and Biological Engineers Paper No. 066077, St. Joseph.

[31] National Research Council (1981) Nutrient Requirements of Goats: Angora, Dairy, and Meat Goats in Temperate and Tropical Countries. National Academy Press, Washington DC, Number 15.

[32] Gardiner, D.T., Miller, R.W., Badamchian, B., Azzari, A.S. and Sisson, D.R. (1995) 
Effects of Repeated Sewage Sludge Applications on Plant Accumulation of Heavy Metals. Agriculture, Ecosystems and Environment, 55, 1-6. https://doi.org/10.1016/0167-8809(95)00610-5

[33] Muir, J.P., Terrill, T.H., Mosjidis, J.A., Luginbuhl, J.-M., Miller, J.E., Burke, J.M. and Coleman, S.W. (2017) Season Progression, Ontogenesis and Environment Affect Lespedeza cuneata Herbage Condensed Tannin, Fiber and Crude Protein Concentration. Crop Science, 57, 515-524. https://doi.org/10.2135/cropsci2016.07.0605

[34] Fasina, O.O. and Sokhansanj, S. (1993) Effect of Moisture Content on Bulk Handling Properties of Alfalfa Pellets. Canadian Agricultural Engineering, 35, 269-273.

[35] Fasina, O.O. and Sokhansanj, S. (1996) Effect of Fines on Storage and Handling Properties of Alfalfa Pellets. Canadian Agricultural Engineering, 38, 25-29.

[36] Schroeder, J.W. (2013) Forage Nutrition for Ruminants. Bull. AS1250. NDSU Extension Service, 1-16.

[37] Militimore, J.E., Mason, J.L. and Ashby, D.L. (1970) Copper, Zinc, Manganese and Iron Variation in Five Feeds for Ruminants. Canadian Journal of Animal Science, 50, 293-300. https://doi.org/10.4141/cjas70-044

[38] Yigit, D., Akar, F., Baydas, E. and Buyukyildiz, M. (2010) Elemental Composition of Various Mulberry Species. Asian Journal of Chemistry, 22, 3554-3560.

[39] Vu, C.C., Verstegen, M.W.A., Hendriks, W.H. and Pham, K.C. (2011) The Nutritive Value of Mulberry Leaves (Morus alba) and Partial Replacement of Cotton Seed in Rations on the Performance of Growing Vietnamese Cattle. Asian-Australian Journal of Animal Science, 24, 1233-1242. https://doi.org/10.5713/ajas.2011.90328 